
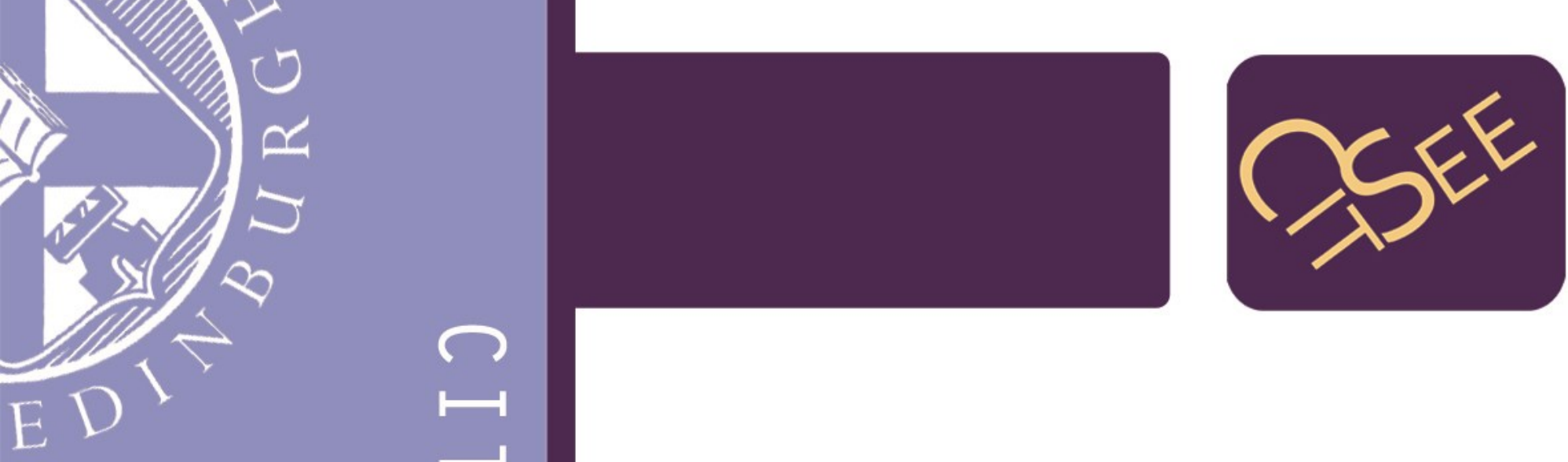

Being an Activist: Feminist citizenship through transformations of Yugoslav and post-Yugoslav citizenship regimes

Adriana Zaharijević

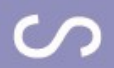

Гा

20

$\mapsto$

Гा

@

Working Paper 2013/28

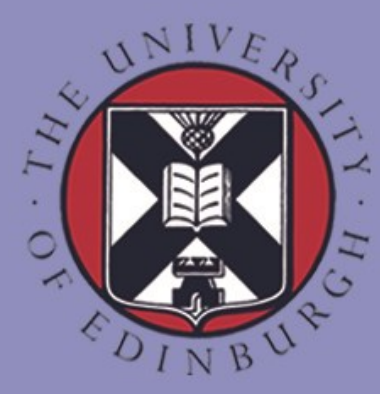

European Research Council 
University of Edinburgh, School of Law

The Europeanisation of Citizenship in the Successor States of the Former Yugoslavia (CITSEE)

Being an Activist: Feminist citizenship through transformations of Yugoslav and post-Yugoslav citizenship regimes

Adriana Zaharijević

The Europeanisation of Citizenship in the Successor States of the Former Yugoslavia (CITSEE)

CITSEE Working Paper Series 2013/28

Edinburgh, Scotland, UK

ISSN 2046-4096 
(C) 2013 Adriana Zaharijević

This text may be downloaded only for personal research purposes.

Additional reproduction for other purposes, whether in hard copies or electronically, requires the consent of the authors.

Requests should be addressed to citsee@ed.ac.uk

The view expressed in this publication cannot in any circumstances be regarded as the official position of the European Union.

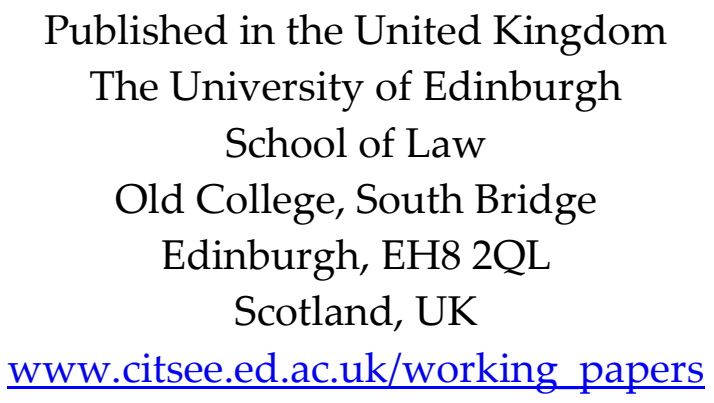

This work was supported by funding from the CITSEE project (The Europeanisation of Citizenship in the Successor States of the Former Yugoslavia), based at the University of Edinburgh, UK. CITSEE is funded by the European Research Council under the European Union's Seventh Framework Programme, ERC Grant no. 230239, and the support of the ERC is acknowledged with thanks.

For information about the Project please visit the project website at www.citsee.ed.ac.uk 


\title{
Being an Activist: Feminist citizenship through transformations of Yugoslav and post-Yugoslav citizenship regimes
}

\author{
Adriana Zaharijević ${ }^{1}$
}

\begin{abstract}
The Yugoslav wars of succession have had a great impact on how feminism in the region has been researched and written about. A lot of significant research has addressed relation of feminism to (anti-) nationalism and peace-building processes, whereas the transformations of citizenship, caused by the multiple changes of the former Yugoslav citizenship regimes, were mainly out of focus. This paper will attempt to connect relevant investigations in feminist citizenship, its meaning and scope, with the alterations of citizenship regimes in the former Yugoslavia and its successor states. The assumption is that one could differentiate between three different citizenship regimes - the first framed by the socialist self-management state, the second by the nation-building processes and violent disintegration of the former state, and the last one by post-socialist, post-conflict transitional circumstances which had also a strong impact on the uneven development of gender regimes in Yugoslavia and its successor states. Feminist citizenship is understood as a paradigm of activist citizenship which contests and challenges the meanings of citizenship itself. It will be argued that feminist citizenship has to be seen as both an effect of deep changes in citizenship regimes, but also as a constant challenge to their sedimentation. The paper will thus seek to offer an alternative reading of history of feminism in Yugoslavia and its successor states, relying mainly on the concepts of activist citizenship and citizenship regimes. It will also show that with the changes in citizenship regime the frames of interpretation change as well, changing the meaning of feminism as a political force.
\end{abstract}

Keywords: feminist citizenship, activist citizenship, citizenship regime, Yugoslavia, post-Yugoslav spaces.

\section{Introduction}

In Nancy Fraser's "Feminism, Capitalism and the Cunning of History", an article well-received in the leftist feminist circles in the post-Yugoslav region, there is a seemingly irrelevant footnote which informs the reader about an omission. "I will follow", says Fraser, "the more conventional path of excluding the region [Communist bloc] from this first moment of my story, in part because it was not until after 1989 that second-wave feminism emerged as a political force in what were by

\footnotetext{
${ }^{1}$ Dr Adriana Zaharijević, CITSEE Associate Researcher. E-mail: adriana.zaharijevic@gmail.com.
} 
then ex-Communist countries" (Fraser 2009, 100, ft. 3). Although Fraser's overall argument did not suffer much because of this historical oversight, one fact needs to be emphasized: there was (second-wave) feminism in some parts of the Communist bloc, in Yugoslavia for certain. Feminism started to gain substantial weight by the end of 1970s, after the seminal conference 'Drug-ca žena' (Comrade Woman: Woman's Question - New Approach, held in Belgrade in 1978), the first of its kind not only in Yugoslavia, but also in Eastern Europe as a whole.

In what follows I will try to uncover the trajectories of feminism which did not emerge in the comparable context of the state-organized capitalism and the Westphalian framework of the welfare state, expounded, for example, by Fraser. I will sketch a very brief history of feminism in the Yugoslav region, relying on the conceptual framework which revolves around two notions, that of citizenship regime and activist citizenship. I argue that this framework can offer more valuable insights into the dynamics of interaction of feminist activism and the state than the concepts of ethnicity or nation, which are far more common in the texts that interpret this specific part of former Eastern Europe. The paper explores two complementary issues: how feminists in the Yugoslav region - as feminist activists - related to the state(s), and how specific kinds of 'feminist citizenship' emerged, first in Yugoslavia and then in its successor states. The purpose of relating feminism and citizenship in this specific contextual framework is also to shed light on what the 'political force', as Nancy Fraser puts it, actually refers to, and how the frames of interpretation change, changing the meaning of political force itself.

It seems somewhat paradoxical that in feminist scholarship issues central to citizenship were not always automatically linked to those related to the state. Judith Squires (2000) gives a plausible explanation for this, referring to the a-temporal, nonspatial 'patriarchal state' of early second-wave feminism. The 'patriarchal state' supplanted historical and geographical states, becoming an emblem of the structurally determined gendered power relations in all places and in all times. However, the space where second-wave feminist action normally took place was bound to polities, and the principal addressees of feminist demands were their respective 'local' states (Fraser 2009, 106). This inconsistency would come to the fore in the 1990s under the joint influence of the fall of the Berlin Wall, the consequent reappearance of citizenship debates, the decline of the welfare state (Lister 1990), the critique of the state as the arena of the feminist political change (Brown 1992), and feminist critique of the nation-state from a transnational perspective (Narayan 1997). The state thus proved not to be a minor issue that could have been so easily overlooked. This was particularly true in the context of Yugoslavia.

In contrast to their early Western second-wave counterparts, Yugoslav feminists did not invent a patriarchal state of their own; they did not criticize the existing one as patriarchal, and they did not make the Socialist Federative Republic of Yugoslavia (SFRY) the primary addressee of their demands. Feminist relationship to the state, however, altered fundamentally with the shift in citizenship regime at the beginning of the 1990s. The collapse of Yugoslav self-management and the 
transition into market democracies had been eclipsed by the violent disintegration of the federal state. The dissolution of Yugoslavia and the subsequent emergence of the multiple states, more often than not defined in ethno-national terms, produced a thoroughly different feminist relation to the state: from being benevolent dissidents, feminists turned into disloyal citizens. The issues of the state and citizenship would therefore become central for the definition of feminism and its oppositional activism itself.

The conceptual framework which allows us to understand this specific nexus between the state and feminist activism revolves around the notion of citizenship regime. The term 'citizenship regime' comprises, as Jo Shaw and Igor Štiks show in their introduction to Citizenship after Yugoslavia, four dimensions: responsibilities of the state towards its citizens, their acquired rights and duties, state governance and broadly defined issues of belonging. It needs to be stressed too that "it is not just formal rules which define a citizenship regime, but also informal ideologies, narratives, beliefs and practices, which are often just as important" (Shaw and Štiks 2012 , 4). In his chapter "Laboratory of Citizenship" in the same volume, Štiks (2012) aptly demonstrated how citizenship served as a tool for the making and re-making of ties between legal status and political belonging in the relatively long history of Yugoslav state(s). Relying on this historical timeframe ${ }^{2}$ and on the conceptual grid provided by Shaw and Štiks, I will argue that the feminist relationship to the state, as the space for the enactment of a certain citizenship regime, changed strikingly with the changes in citizenship regimes.

From the emergence of the Yugoslav second-wave feminism in the mid-1970s, there were two successive shifts in three citizenship regimes. The first citizenship regime was enacted in the SFRY, whereas the first shift refers to the transformation of a multinational socialist federation into a multitude of mostly ethno-national states, whose citizens, formerly workers and 'self-managers', rapidly transformed into Serbs, Croats, Montenegrins, Slovenes, etc. The second citizenship regime was marked by the violent disintegration of the former state and the nation-building processes. It is, in effect, related to the transformation of the state, the emergence of new borders and constitutionally defined exclusionary citizenships. The last citizenship regime is being enacted in the post-socialist and post-conflict states which are still in the uneven process of political, social and economic transition. Although they can be discursively differentiated, these citizenship regimes also overlap and each builds upon the remnants of the previous one. In different successor states, similarities aside, these regimes had - and have - their own peculiarities.

Transformations of citizenship regimes were followed by equally deep changes in gender regimes. This iterative relation between shifts in citizenship and

\footnotetext{
2 One significant deviation from that timeframe needs mentioning. Štiks begins his historical overview in 1918 when the Kingdom of Serbs, Croats and Slovenes was established. My analysis focuses especially on the last four decades and begins with the post-war socialist state of Yugoslavia, because it was only then, in 1946, that women won the right to vote and gained political, and most civil and social rights.
} 
gender regimes in (post-) Yugoslav contexts produced a peculiar kind of citizenship as well. I define 'feminist citizenship' as directly related to the state(s), acts of dissent, and the questioning of the "singular loyalty, identity and belonging" (Isin 2009, 368). Holloway Sparks' notion of dissident citizenship (1997) comes to mind here. Since feminists (all around the world) partake in different - discursive, performative, organizational, and everyday life - types of dissenting practices, they could be seen as the model of "engaged, active and self-governed citizens" (Sparks 1997, 83). However, what I want to stress in this paper is not an active, but emphatically activist dimension of feminist citizenship: one which, in a certain sense, even opposes active citizenship.

Connoisseurs of the regional feminism might find this odd: was it not that Yugoslav feminism was all about theory, French, when it comes to that? In order to abandon this unfruitful division between theory and activism, I will rely on Engin Isin's concept of activist citizenship elucidated in his article "Citizenship in Flux: The Figure of the Activist Citizen". "Thinking about citizenship through acts", says Isin, "means to implicitly accept that to be a citizen is to make claims to justice: to break habitus and act in a way that disrupts already defined orders, practices and statuses" (Isin 2009, 389). But what exactly is an act of citizenship? In a similar vein to Isin, Rosi Braidotti (2013) defines it very broadly, as "whatever increases your capacity to act and intervene in the world". But there she almost equates this intervention with disobedient acts of citizenship, highlighting that even when they are profoundly negative - as acts of resistance and protest - they are also always productive, even creative modes of intervention in the world.

Thus, it might be argued that to be active and activist citizens is in fact quite dissimilar. Active citizenship could be described as direct participation in public affairs (Isin 2009, 382), or as a constant process of building a citizenship regime and making its rules as diverse as possible. On the other hand, as disruptive, activist citizenship is something which undermines and subverts the rules of enactment of a certain citizenship regime. Referring to Isin, Lynn Staeheli emphasized the difference between active and activist citizenship in an even more unambiguous manner: active citizenship has a goal of getting things done, whereas activist citizenship has a goal of challenging and perhaps transforming the status quo (Staeheli 2011). In this paper this difference will be further emphasized by Faranak Miraftab's useful distinction between invited and invented spaces of citizenship: the former referring to the legitimized spaces of action, while the latter are, contrarily, in confrontation with the "authorities and the status quo" (Miraftab 2007, 1).

If Isin is right that citizenship as status and practice has its foundations in masculinity, warriorship and property, then feminism calls into question the given nature of that body politic, if in multiple and non-linear ways. Although historically feminism fought for the admittance of women into active citizenship, feminist citizenship might in general be described as a form of activist citizenship. Due to the changing nature of the state and its citizenship regimes, in a (post) Yugoslav context this description becomes particularly accurate. In order to build this argument, I will 
expound this conceptual framework within three citizenship and gender regimes that generated feminist citizenship peculiar to the Yugoslav and post-Yugoslav region. I will argue that feminist citizenship has to be seen as both an effect of these deep changes, but also as a constant challenge to their sedimentation. As activist citizenship, feminist citizenship disrupted defined - socialist, ethno-nationalist or liberal-entrepreneurial - orders, practices and statuses, or fiercely called them into question. $^{3}$

\section{Citizenship Regime No. 1: Yugoslav Feminist Citizenship}

\section{"Mlada partizanka pušku nosila"4}

Susan Gal defines feminisms as political movements that are perforce embedded in the particular gender regime and the historical moment from which they emerge (Gal 1997, 93). This definition aimed at capturing differences on the global level, particularly in the context of the East/West divide, still relevant at the time. But bearing in mind that changes in citizenship regimes - in institutional arrangements, responsibilities of the state, responsibilities of its citizens, and their sense of belonging - necessarily generate change in gender regimes, Gal's definition is also applicable on more local levels. It is thus in the light of this embeddedness that we can explain the chasm between two - temporally close, but essentially disparate visions of the political subjectivity of women. The first was provided by the new socialist regime which granted Yugoslav women full citizenship rights immediately after World War II. This act was a consequence of the belief that elimination of gendered exploitation and egalitarian distribution of wealth were inseparable, as well as the belief in the inevitability of the social elevation of women, especially when they fought for the establishment of the socialist state in such great numbers (Woodward 1985). Only some fifty years later, this gender and citizenship regime endured a profound transformation. So did contexts, scales and terrains of emancipation which provided the second vision of emancipatory politics. This one, devised in the 1990s, did not draw from the legacy of partisan women who fought for their country. It drew on Virginia Woolf's metaphorical statement according to which women had no country.

\footnotetext{
${ }^{3}$ In terms of methodology, this paper is largely based on analysis of primary sources, discussion of the relevant secondary literature written about the region, and direct observation of the political domain. The small number of interviews with elite informants is also an important methodological part of this research. Feminism which developed during the first and the second citizenship regime is well documented in BHS languages, but also in English. Therefore, I conducted interviews only with women who are presently deeply involved with feminist politics (see also footnote 23) in order to supplement my primary sources, because of the relative inaccessibility of data pertaining to the contemporary post-Yugoslav political space.

4 "Young partisan woman carried the rifle", a verse from the popular partisan, and later children song “Mlada partizanka".
} 
The socialist revolution brought women institutionalized equality, entrance into the redefined public arena, and a constitutional promise, in line with an everopen unfolding of socialism, of total emancipation. The first post-war constitution guaranteed voting rights to all citizens regardless of sex (Constitution of 1946, Art. 23). Women were also proclaimed equal with men in all spheres of economic, state and social life, and their place in the production process was supposed to be especially protected (Art. 24). The partisan authorities had ideologically endorsed full equality already during the war (Pantelić 2011, 37). Thus, it is not surprising that the programme of the People's Front in 1945 emphasised that now, when equality has been achieved, the basic assignment of every adherent of the Front must be further consolidation of that equality and full participation of women in all areas of political and social life (Ramet 1999, 95). The dissociation from Stalinist statesocialism and the subsequent introduction of a specifically Yugoslav selfmanagement system, promised to eradicate alienation, injustice and inequality completely.

However, in decades to come, along with the significant changes in the economy, foreign policy and internal institutional arrangements, the political subjectivity of citizens also altered. In the Constitution of 1946 the power was first vested in 'the people', while three decades later, in the last Yugoslav Constitution of 1974, it belonged to the 'working class and all working people' (Con. 1974, Art. 88). In terms of gender regime, this is significant for two reasons, especially when combined with one of the state-founding myths - that women's new role was won in the war. The revolutionary partisan woman who had won her emancipation with the rifle was displaced by the socialist working mother. The 'self-abolishment' in 1953 of a wartime political organisation, Women's Antifascist Front (AFŽ), of central importance in post-war emancipation of women throughout Yugoslavia, was instrumental in this change of imagery. To quote Tito, now that revolutionary struggle in which women took active part in unprecedented numbers was over, "communists ought to be at the forefront in the struggle for ...affirmation of [women's] social role", their unique and socially responsible role as working mothers (Tito 1979, 2). For a short time, the equality of women had its own - however partial and unstable - status until 1953, when it turned into "a common social question, the question of the common struggle of all forces of socialism led by the League of Communists and Socialist Union of Working People" (quoted in Pantelić 2011, 127). ${ }^{5}$

\footnotetext{
${ }^{5}$ The quoted text is from the Resolution on the creation of League of Women's Societies (LWS), an umbrella organization which was designed to replace an overly political and overly emancipatory Women's Antifascist Front. Ivana Pantelić also enumerates what those women's societies were dedicated to: improvement of domestic sphere, enlightenment of women and mothers, care for the upbringing and health of children, creation of institutions for children, such as school kitchens, etc. Neda Božinović, a former partisan and the peace activist during the last decade of her life, wrote in Žensko pitanje u Srbiji u XIX $i$ XX veku (still the only comprehensive reading material on Serbian and Yugoslav women's history) that "the great number of women delegates experienced conclusions on abolishment of AFŽ, i.e. the establishment of LWS, as a degradation of women's organizations and of women themselves. Many AFŽ activists then simply decided to stop working" (Božinović 1996, 174).
} 
The woman question was thus abolished as potentially singular and separate in nature. In the next two decades, the class issue, as the core social issue to which all others might ultimately be reduced, gained exclusive prominence. And as the class issue was treated as solved and the woman question was an integral part of the class issue, it could be resolved that "the woman is today formally and actually equal in our society" (Koprivnjak 1980, 10). Women were perceived as members of the working class and representatives of the working people, with the specificity which merited particular protection. The full citizenship of women as equal, as emancipated through work, and as protected as mothers, was taken to be self-evident. This is the climate in which Yugoslav feminism began to foment.

\section{Feminists as Benevolent Dissidents}

Feminism in the 1970s was not perceived as a continuation of the brief post-war emancipatory struggles led by AFŽ. What was later called 'state-feminism' was far more in line with the way 'communist women's lib' was conceived. ${ }^{6}$ It was, however, not an exact equivalent to 'Western feminism'. It shared a different tradition in terms of suffragism, a different political, social and economic context, and differently constructed the gendered identity around which it organised its (mainly intellectual) struggles. Chiara Bonfiglioli's analysis of the articles of Italian feminists after the Drug-ca conference in 1978, shows that misunderstandings between 'Western' women and their hosts were rife, because, according to Italian guests, Yugoslavs did not want to abandon the "old emancipationist line: work, laws, services, social integration, and construction of socialism" (Bonfiglioli 2011, 119). The circumstances created by the socialist state were relevant for the positioning of the first Yugoslav feminists. Blaženka Despot praised socialist self-management as an alternative societal model to both bourgeois and etatist modes of production, which also offered "qualitatively new socialism founded on non-authoritarian relations" (1987, 43). Bearing this in mind, nothing, not even the constitutional equality of women and men, should be used to preclude questioning of their relations and subordinating 'women's question' to the class problem of the proletariat (Despot 1981, 112). This

\footnotetext{
${ }^{6}$ The difference between state approved women's organizations in SFRY and the emerging feminists is an important one. To elucidate it, I will use here Miraftab's distinction between invited and invented spaces of citizenship. While I am conscious that I am transferring a historically embedded notion into another historical and symbolic time, I believe that this distinction can be useful also in the context at hand. In the socialist era, the representatives of the somewhat satirically called statefeminism (Jalušič 1999, 112) occupied the invited spaces of citizenship, whereas Yugoslav feminists had to invent the autonomy of their own space, at times openly against state-legitimized organization. "The Conference for the Activity and the Role of the Women in the Social Development of Yugoslavia" was the name of one such organisation, which succeeded the disbanded League of Women's Societies and AFŽ before that. In the two citizenship regimes which would come later, the differences between the invited and invented spaces are evident, sometimes glaringly so. In this case the slight, occasionally almost imperceptible differences in language, registers, overtones, such that one can easily slip over today, were quite telling at the time.
} 
was explained in various, albeit similar ways. Despot herself insisted on the fact that emancipation of the working class in the socialist self-management would not be possible without a viable solution for the "women's question" $(1987,44)$; Nada LerSofronić insisted on the historical primacy of the reification and subordination of women (1981, 74); whereas Vesna Pusić took this as her point of departure for the differentiation between equality which has been already achieved, and emancipation which has yet to come $(1980,168)$.

The socialist ideological frame was pivotal for the self-definition of the Yugoslav women's movement, which was largely understood as the "contribution to the struggle for the socialist transformation of the society as a whole, contribution from a specifically women's perspective" (Drakulić 1984: 178). Only through the women's movement, it was believed, does the "realization of the totality of revolutionary movement" become historically possible (Milić 1981: 11). Confronting the critics and those liberal versions of feminism from 'abroad', some feminists like Nadežda Čačinovič insisted that "contemporary feminist problems can be examined radically only in the Marxist way" (Čačinovič-Puhovski 1976: 127). However, Yugoslav feminists agreed on the point that proper Marxist analyses failed to take into account the gendered asymmetry between equality and emancipation, and they questioned the quality of emancipation if it "neglected the 'women's half of the reality'" (Papić 1987, 29).

There was no unanimity about the scope and form of emancipation. Local and non-local scholars underlined later, after the fall of Berlin Wall, that socialism did not emancipate women as equal citizens but only as worker-mothers (Einhorn 1993, 40). Merging women with the working people or proletariat never went beyond their emancipation as animal laborans in the Arendtian sense of the term: emancipation of women as workers utterly failed to produce "women as political beings, that is, citizens" (Jalušič 1999, 112). I would nonetheless argue that this type of analysis was substantially influenced by the political context of the shift in the citizenship regime after the demise of communism throughout Eastern Europe. In the now former Yugoslavia this discourse was especially important because it underlined a certain continuity between the socialism and barbarity of ethno-nationalisms: both hindered the advancement of the then idealised liberal democratic citizenship.

But in the socialist citizenship regime itself, the concepts of citizen, mother, and worker were not in dispute. If there was something controversial with the fact that women were principally regarded as worker-mothers, then the heart of controversy was in the fact that, to quote Barbara Einhorn, there was no equivalent definition of men as workers and fathers $(1993,5)$. The citizenship of men was similarly defined through the identity of their work, but their parenthood was ordinarily omitted. On the other hand, to understand a woman as a working man capable of giving birth, thus protected but otherwise in all other things equal, proved to be too reductive. And this was the space where Yugoslav feminism found a nook of its own. 
"The socialist revolution has not always been able to cross the threshold of the family" (Morokvasic 1986, 127). This cautious statement, extracted from one of the rare texts written in English about women in Yugoslavia during the socialist era, reveals the private sphere as the principal domain of feminist action. Not only in the family, but also in the trams, in the street, in the tavern, in the school and workplace, the micro-battles still had to take place (Drakulić 1984: 178). "The 'Private sector' of life was not even touched by the economic analyses" (Iveković 1987, 22), and this sector, our domestic everyday life, has a "very strong impact on the relations in the self-management society in general" (Rihtman-Auguštin 1980, 85). What feminists had to do, therefore, was to concentrate on what was passed over in the strictly Marxist circles. The private became the task, as Rada Iveković put it, of women's studies and women's movement (Ibid).

In one of her texts about feminism in Yugoslavia, Sabrina Ramet states that Yugoslav feminism did not speak - and here she adds an unambiguous of course - of "overthrowing socialism, but it did speak of the need to overthrow patriarchy and the failure of socialism to do so" (Ramet 1995: 226). Since the state was not the primary addressee of their demands, because it enabled the institutionalisation of equality, feminists did not question the state apparatus. Socialist system, on the other hand, promised to work towards the full emancipation of the human being, and feminists saw themselves rather as the allies than the foes of that cause. If patriarchy was to be found somewhere, it was neither in the state nor in its socialist structure. What will later become known as the 'socialist patriarchy' - and some authors are more (Duhaček 1993, Kesić 2001) or less ambivalent (Papić 1992, Bollobás 1993, Miroiu 2007) in this act of naming - did not exist under this name before 1989. Before then socialist citizenship was not seen as masculinised, to use Kathleen Jones' phrase $(1997,2)$. The state will become patriarchal, and patriarchy will become intrinsic to social and political structure of the socialist rule, but only in retrospect, and not before the socialist systems ceased to exist.

Nevertheless, what Yugoslav feminists did, especially in comparison to 'statefeminism', was - beyond any doubt - a form of dissidence. A self-managing socialist state was necessary, but not sufficient for the full emancipation of the human being, regardless of its gender. Going against the grain of the state dogma, they insisted that emancipation needed an intrinsic supplement. And insisting on this 'supplement' can be seen as what Isin terms an activist claim to justice (Isin 2009, 389), something that, however cautiously, broke the habitus of that citizenship regime and disrupted its defined orders, practices and statuses. In that sense, Yugoslav feminists might be properly termed 'benevolent dissidents' who in their quest for the widening of the space of emancipation stumbled upon a different kind of the political.

Although the material to probe my thesis is scarce and there is no notable use of the term 'citizenship' in the socialist context, contemporaneous or posterior, I will still insist on the concept of feminist citizenship here. To all appearances, defining Yugoslav feminists in terms of activist citizenship, in terms of undermining or subverting the rules of enactment of socialist citizenship regime might seem far- 
fetched. It might be said that they were simply discovering patriarchy - through domestic violence, unpaid labour in the home, sexism in culture, education, and media - and the identity of a woman as a non-reducible entity. Their critique of patriarchy did not assume the parallel critique of the state or its socialist structure of governance. However, their activities, labelled by the state as 'un-institutional' (beyond the embrace of the state) and therefore apolitical (Iveković and Drakulić 1984, 736), were political in a thoroughly new and subversive way. Therefore, it is precisely this un-institutional character of their action that can be seen as a precursor of the civic activism - feminist and non-feminist - of the 1990s (Bilić 2012, Stubbs 2012).

\section{Citizenship Regime No. 2: Feminist Citizenship in the Successor States}

\section{As Women We have no Country}

Compared to feminists as estranged citizens of the newly formed states after the break-up of Yugoslavia, those benevolent dissidents seem benign. But if they are perceived as agents of transformation during the socialist citizenship regime, however modest that transformation was, and as endowed with the rights and the capacity to participate, dissent and network, Yugoslav feminist citizenship might be regarded as the harbinger of the future civil society. ${ }^{7}$ One might only speculate about the future of Yugoslav feminism and of the prospective dissidence of the feminist activist citizenship in a state which would cease to be socialist but would have remained federal Yugoslavia in other respects (or, even harder to imagine, which would have remained socialist but without Yugoslav federal framework). This, as is widely known, did not happen. Benevolent dissidents were thus turned into disloyal citizens almost overnight.

To understand this shift, one has to take into account the frame and the scope of the transformation of the socialist citizenship regime into the nation-building citizenship regime. In times of the dismantling of multinational federations, SFRY was not the only state confronted with internal breakdown, an ensuing 'constitutional nationalism' (Hayden 1992) and the quest for absolute congruence between the state and ethnic community. However, the violence involved in its dissolution highlighted these processes, putting the issues of citizenship on the agenda quite distinctly: What were the responsibilities of the state(s) towards their

\footnotetext{
7 The significance of civil society in the post-Yugoslav region changed dramatically: from the most progressive force in the 1990s, civil society is now seen as representing something rather conservative. But one has to be wary to not apply this statement too rashly and in neglect of the specific context of the 1980s or, for that matter, the 1990s. Paul Stubbs showed how the logic of use of the term 'civil society' changed in the last two decades - from an aspiring frame of activism, to the taken-for-granted institutional paradigm, and finally to the largely irrelevant frame for activism itself (Stubbs 2012, 14; Stubbs 2007). Stubbs subtly caught these differences in the title of his paper by moving from networks, to organizations and to movements of today.
} 
citizens? What rights did citizens have in their states? How to measure belonging to the community (and what community)? And how have the state policies been used intentionally in order to produce a new type of ethno-national citizens? ${ }^{8}$

To distinguish paths into post-socialism in Yugoslavia from other parts of the former state-socialist Europe, I will insist on two different successive citizenship regimes - the one which existed during the war, and another which emerged into the post-conflict space. Just the collapse of real socialism after the fall of Berlin Wall alone would have produced - and did produce in other places - monumental changes in what constitutes the citizenship regime. The new emphasis placed on civil and political rights diminished the significance of the existing social rights; the responsibilities of the state were gradually reduced; the structure of governance altered completely; and the issues of belonging and allegiance changed with the transformation of the socialist to the nation state. But in Yugoslavia these processes were overshadowed by the wars and their immediate effects. Therefore, in line with what Renata Jambrešić-Kirin said, that it is "ruthless and oversimplifying to observe the position of a civilian in war in the same way as the position of liberal individuals in a free society" (2000, 289), I propose a distinction between "nation-building citizenship regime" and the "transitional citizenship regime". Although they overlapped, ${ }^{9}$ they cannot be seen as indistinguishable because the position of citizens changed fundamentally when the war(s) were over and the proper economic transition into neoliberal capitalism began. In other words, when the "nationbuilding citizenship regime" ended, citizens in combat, internally displaced, expelled, imprisoned, raped, tormented, bombarded, citizens living under international sanctions, without a house, without a village, without a state, were turned into citizens of the newly formed nation-states that were in the process of transition to free market democracy. These processes will become central for what is in this paper understood as the third citizenship regime.

If earlier there was a telling discursive shift from 'the people' to the 'working class', then with the anticipated arrival of democracy the new shift in the meaning of 'the people' took place (Mimica \& Vučetić 2008). By the end of the 1980s the only

\footnotetext{
${ }^{8}$ The collection Citizenship after Yugoslavia offers a synoptic view on these issues, dealing specifically with each post-Yugoslav state (Shaw and Štiks 2012).

${ }^{9}$ At this point the commonality of SFRY context ends as well. The main reason for this is different territorialisation of violence and different dynamics of development within the former republics of SFRY. For example, Slovenia, the north-western socialist republic of SFRY was the first to declare independence in 1991, was the birthplace of the subsequent Yugoslav wars for succession, was the first to enter into the process of transition (unencumbered, at least directly, by the violent conflicts), was the first to enter into EU, and the first to protest against austerity measures and the economic politics of its government. The comparison of Slovenia and Serbia, Kosovo or Montenegro, for instance, is not self-evidently justified, even though they were part of one and the same federation for a considerable portion of time. Therefore, although differences seem to outnumber the commonalities between the states which unevenly emerged out of SFRY, I will still insist on the framework which applies differently to all seven of them, the framework which recognizes a post-socialist and conflict phase and a successive post-socialist, post-conflict phase.
} 
political dimension of 'the people' became the ethno-national one: 'the people' would turn into nations. The ethno-national intra-state organization was, however, not a novelty, because it had already been part of the earlier socialist citizenship regime: ethno-national groups, with the exception of Bosnia and Herzegovina, were territorialized as constitutive peoples inside the Federation (Ragazzi 2011, Hayden 1999), which nevertheless secured the participatory rights of the national minorities living in all socialist republics. Thus, when democracy was introduced it was with the view to restore the plurality of the people. But the political dimension of the people', by now entirely reducible to the national dimension, was instrumental not in promoting plurality, but in instituting a specific - ethno-national - form of community. Rather predictably, ethnically defined republics did not, as Štiks says, "adopt civic democracy as republican communities of citizens which negotiated or confronted each other over the future of their common state (union or separation?)" (Štiks 2012, 22). The question now was how to produce congruence between the ethno-national communities and republican communities of the Federation. And the question was vital because undivided membership of both communities was needed in order to be a 'belonger' to a certain citizenship (Verdery 1996, 293). The coincidence of the collapse of the socialist regime, the advent of democracy which could have been - and had been - used either as an ideal framework of the rule by the people or as a tool for fragmentation, and the revamping of ethnic animosities, led to the wars of Yugoslav succession.

Gender regimes changed correspondingly. I will illustrate this with two points about the widely recognized de-politicisation or instrumentalisation of citizens according to their gender (Gal \& Kligman 2000): politics of reproduction, common in the post-socialist East and Central Europe, and the use of rape in the Yugoslav wars. The socialist working mothers were constructed as both natural and social beings, and the state had to protect the natural dimension and to encourage the social. The post-socialist nation-building processes relied on suppression of the social dimension, and on evocation and attempted restoration of a bread-winner type middle class nuclear family, which became a constitutional subject with its own rights, for example, in the first Slovenian and Croatian Constitutions (Antić 1992, 168). Most often contrary to the reality itself, women were now presented exclusively as mothers and valued as reproducers of longevity of the nation. Placing motherhood on a pedestal served to discredit the "debilitating 'mothering' of socialism" (Verdery $1996,80)$, to denounce women's emancipation "as a salient and disgraceful trait of 'so-called' socialist societies" (Heinen 2006, 83), to shape and re-shape the nation in terms of wanted and unwanted populations (Zajović 1995a, Krasniqi 2011), and to name the enemy obliquely - for example, by defining abortion in Croatian nationalist propaganda as "a vestige of Serbo-communism" (Pavlović 1999, 138; see also Jalušič 1999; Ćetković 1998).

Within the post-socialist "conservative, traditionalist, nationalist and simpleminded" democracy (Papić 1992, 101), women came to be politically regarded as the 
mere reproducers of the nation. ${ }^{10}$ This 'demographic transition' (Drezgić 2010, 13), which alternated pronatalist and neo-Malthusian discourses in correlation to 'whose' women were in question, naturalised, privatised and depoliticised women's membership in the community. Through their naturalisation, women lost political or social agency and became personifications of the nation they accidentally belonged to. This was especially evident in the case of war rapes, the ultimate form of objectification and gendered weapon used for advancing systemic demographic transition. In the processes of post-socialist redistribution of ethnic/gender power and nation-building, as Žarana Papić (2002) has argued, the politics of reproduction and rape need to be seen as interdependent forms of violence against (ours and their) women. Thus, in addition to constitutional nationalism and the ideology of patriotic motherhood, the wars produced an opportunity for the use of the woman's body not only as the site of revenge, but as the vessel for future 'belongers', i.e. ethnically moulded prospective citizens.

Feminists as Disloyal Citizens

Where are you from? From Yugoslavia. Does that country exist? No, but I still come from there. (Dubravka Ugrešić, quoted in Pavlović 2001, 132)

One of the resolutions at the first conference of the Network of Yugoslav Feminists in 1987 was that they would not acquiesce with artificially made male barriers, "that they were united in sisterhood, and their common experiences as women over-rode male concerns for territorial rights and geographical boundaries" (Batinić 2001, 6). At the beginning of the 1990s, feminists were still ambivalent in terms of the instance to which they addressed their demands. ${ }^{11}$ Their dissidence continued, because they did

\footnotetext{
${ }^{10}$ This statement is highly problematic, but it was referential for many local and non-local interpreters for more than a decade (see Zaharijević et al. 2012, Iveković 1993). Instead of a mere dismissal, I argue that it has to be re-thought and contextualized anew. Sandra Prlenda Perkovac, historian from Zagreb, insists, for example, on the fact that the violent dissolution mobilised both men and women to become active citizens: "Despite the fact that nationalism ascribed women the key role in traditional, domestic and reproductive settings, this was also the time suffused with the rise of democratic ideals of open political debates, however nationalist in orientation. All were invited to take part in them" (Private interview, 6.2.13, Zagreb). Jelena Višnjić, media theorist from Belgrade, emphasized that one should rather think in terms of instrumentalisation of women (Private interview, 17.1.13, Belgrade), which also impacted on the rise and diversification of feminist activities. The need to highlight the strongly political role of women in post-Yugoslav feminist movement was common to most of my respondents from Macedonia to Bosnia and Herzegovina.

${ }^{11}$ The "Minimal program of women's demands", issued in 1990 by a Belgrade based group Beogradski ženski lobi (Belgrade Women's Lobby), in which many notable activists participated, might be used as an example. It begins with the demand from the Lobby to the parties and movements ('stranke, partije i pokreti') to include women's demands and women's perspective in all their programmes. Those demands would include fair politics of employment, shorter workday, non-sexist education and upbringing, reproductive rights, the naming of the acts of violence and its criminalisation, the opening
} 
not unequivocally embrace the liberal democratic citizenship, which was often perceived as conservative and backwards because of its emergent ethno-nationalist dimensions. But the new democratic setting also enabled them to speak about women's questions with no restraints and to insist that in a democratically open debate this issue cannot be subordinated or reduced to any other. This is the time when the vocabulary of citizenship began to be used, and the feminists focused on women as active citizens in the emergent pluralist setting - as those who by the active use of their political judgment should cultivate their political subjectivity and thus have to be present more equally in the public and decision-making processes.

In 1991, when the common state began to crumble, the entity which was in control of maintaining the boundaries of belonging, participation and entitlement became quite elusive. The issue of rights and responsibilities was increasingly conceivable only in terms of membership in the ethnically defined communities inside the common state. Therefore, the frontiers and enlargement of these communities, which was perceived as the task of the patriotic female citizens, were of vital importance. The issues of loyalty and belonging were inextricable from constitutional arrangements and other administrative policies that produced implicit inclusions of belongers and exclusions of those who were ethnically 'incongruous'. But belonging did not refer only to a static (ethno-national) identity. It could have been induced (for example, through rape in wars) or denied to those who refused the simplistic equation of citizenship and ethnicity.

The crumbling of the common state and the ensuing wars of succession produced a deep change in feminist citizenship. The issues of frontiers and belonging were central for the transformation of the benevolent dissidents into disloyal citizens. Contrary to the politically ambivalent and ambivalently Yugoslav feminism of the 1970s and 1980s, feminism of the early 1990s became preoccupied with the state: whose state that was, what were its borders, who belonged, who did not and why, and what was the price of the unreserved loyalty one was expected to give to the newly formed nation-states. Finding themselves territorialised in the non-chosen successor states, feminists refused to accept their new citizenship if it overlapped with an imposed ethnicity. ${ }^{12}$ And ceasing to be Yugoslav feminists, they chose to be

of women's health centers and free contraceptives, etc., but the phrasing of these demands shows that they were not articulated with a specific addressee in mind (in Ćetković 1998, 19-23).

12 This is the moment to again evoke Miraftab's useful distinction between invited and invented spaces of citizenship. Not all feminists subscribed to the idea that 'As Women We Have No Country'. There are plenty of papers discussing the division between patriotic and non-patriotic feminists (or nationalist and non-nationalist, depending on who was performing the act of naming) over "the logic of the victim" (see Benderly 1997, Ristanović 2000, Batinić 2001, Žarkov 2003). The aforementioned issue of rape proved to be a stumbling block where both feminism and allegiance to the states was tested. The fact that patriotic, official or state-supported feminists (Jansen 2005) - present in all former republics/new nation-states - embraced the ethno-national citizenship regime, granted them with a certain visibility which was vehemently denied to those branded as traitors or collaborators. On the other hand, it also provided common ground for an invention of the outcast position, and 
only feminists, as if feminism itself provided the space of citizenship. Lepa Mlađenović said in 1992:

We, the feminists [in Serbia] are currently in a crevice, without a national identity. We were Yugoslavs [Jugoslovenke], but that concept does not any longer comprise everything that it used to - it is now reserved for Yugo-Serbs and we are not Yugoslavs anymore. And to be Serbs [Srpkinje] now looks like siding with the ruling politics. And that is impossible. Well, in any case, I am a woman; feminist, lesbian and I do not care about not having a national identity (quoted in Bilić 2012, 95).

Although Mlađenović underlined the aspect of national identity, which was discursively the most powerful denominator of its time, I will insist that nation cannot be the concept that has the power to unify feminists - even in its most allegorical forms. But, far more importantly, when used as a referential framework, 'nation' does not provide an understanding of the convergence of several decisive elements: the disappearance of the common socialist state; the parallel appearance of the exclusionary communities which did not accommodate the commonality Yugoslav feminism used to have; ${ }^{13}$ feminist transnationalism, which went hand in hand with the outright and emphatically activist support for peace and the conscious disidentification with the new states, either those perceived as aggressors-states or those seen as the victims.

In her persuasive manifesto of feminist disloyalty, Staša Zajović from Belgrade Women in Black expounded the principles of feminist disownment of the nation, state and fatherland. Not accepting the imposed ethno-national citizenship meant protecting the right to self-determination and autonomy. But it also involved rejection of militarist ideology and the logic that the state could be a victim, and refusal of patriarchal politics which divides women on the basis of ethnicity and denies solidarity between them (Zajović 1995b, 51). This understanding that women, especially those who were the direct victims of wars, were the mere instrument in the process of consolidation of borders ${ }^{14}$ produced a distinctly feminist non-belonging to their new imposed citizenships. This is the context in which the famous phrase - I as a woman have no country - gained currency. In a more poetic manner, this could also be described as the homelessness at home (Jambrešić-Kirin 2000, Šeleva 2004,

strengthened the bonds of solidarity between those who purposely chose feminist citizenship (Dobnikar 2000).

${ }^{13}$ Rada Iveković succinctly illustrates this point in 1998, when the journal Kruh $i$ ruže marked the $20^{\text {th }}$ anniversary of feminism in Croatia. Iveković said that "the story of Zagreb feminism, or feminism exclusively in Croatia, may be interesting; but it is very incomplete if one does not account for encouragements and efforts that were given to it from other important centers within former Yugoslavia" (quoted in Pavlović 2001, 149).

${ }^{14}$ As Biljana Kašić said, "I felt how from one day to another blaring emotions turned into political messages, the women being merely their instruments. 'Nationalistic rape', 'the barbaric syndrome', 'raving Chetniks'. I was searching for women" (Kašić 1995, 126). 
Petrović 2009), the homelessness of women which could have been surmounted only through relentless activism: unyielding disruption of solidification of the new nationbuilding orders. Making claims to a justice that was beyond ethnicity helped in making the common sense of de-territorialization of feminists their common ground for action. Thus feminist citizens can be defined as women who deliberately chose to trade their particular ethno-national identity for an abstract, activist public self. ${ }^{15}$

Feminist citizenship in the successor states can be defined as consciously political - anti-nationalist, anti-war, but also anti-state - and profoundly activist. It was non-ethnic and non-state, yet it was territorialised. The space which used to be Former Yugoslavia, now carved with borders, enabled the emergence of feminism as the space of citizenship. This does not imply an intrinsic Yugo-nostalgia: in truth, feminist allegiance went neither to the now non-existing state, nor to those newly formed. Choosing feminism meant choosing to be contentious with the state which one became a citizen of overnight. Choosing feminism meant disregard for the frontiers, disloyalty to the nation and the state to whose citizenship one succeeded, and rejecting the new, ultimately ethnic foundation of citizenship.

\section{Citizenship Regime No. 3: Contemporary Feminist Citizenship}

Probably the most powerful articulation of this specific positioning - of feminist deliberate displacement or feminism as the space of citizenship - was given by Žarana Papić in one of her recorded lectures, delivered during the last years of the 1990s $(2012,27)$. She insisted on the significant political potential in the feminist initiatives of the former Yugoslavia, precisely because it was only feminists who had not been seduced - or willing to be seduced - by nationalism; who were not nostalgic about the socialist era, despite the fact that the socialist order had positive effects on women; and who did not let themselves be deceived by the early euphoria of parliamentary democracy which in actuality significantly diminished the presence of women in politics proper. ${ }^{16}$ What Papić saw as a distinctly feminist political force was primarily definable as the constancy in openness or readiness to transgress the imposed borders, both physically and symbolically.

In 2002 this readiness came to be actualised as a form of subverting the orders of memories and frontiers, fittingly termed "Women Activists Cross the Borders" (see Deschaumes and Slapšak 2003), when 47 women from all former Yugoslav republics and Albania spent two weeks crossing the real and imagined borders mounted between them. Since it was possible only outside of the borders of the

\footnotetext{
15 The exact sentence from Jones' Introduction to the special issue on Citizenship in Feminism in Hypatia is "To become a citizen is to trade one's particular identity for an abstract, public self" (Jones 1997, 2). Julie Mertus makes a similar claim when she is discussing women's activism in Kosovo, insisting on the fact that in order to be "women's rights activists, Serbian women had to choose their gender identity over their identity as Serb" $(1999,172)$.

16 The return of the first democratically elected MPs in Yugoslavia as a whole was 63 (4.4\%) women and 1272 (95.6\%) men in parliaments (Antić 1992, 174).
} 
country one suddenly and enforcedly belonged to, feminist citizenship in the 1990s severed the ties between citizenship and nation-state. It assumed blending of the local and the trans-state and also, increasingly, the supra-state communities, thus transversally expanding the notion of citizenship itself (Yuval Davis 1999). And the political potential of this space of citizenship was, as Paula Zore, an activist from Dubrovnik, said, in the decision to be "stubbornly and constantly on the margin - the only place where one could be a feminist, that is, critical and autonomous". ${ }^{17}$ The vision of non-essentialist, open and pluralist, participatory, value-oriented instead of identity-oriented citizenship is expressly the legacy of the feminist citizenship which emerged in the 1990s. ${ }^{18}$

But the circumstances in the region changed fundamentally again with the cessation of conflicts. The dissolution of SFRY was uneven and it is for this reason that the timeframe of the nation-building citizenship regime was not precisely defined. Some successor states began their proper transitional development in the mid- or late 1990s, with or without major disruptions. Redefinitions of the frames of sovereignty of some states were yet to come (see Vasiljević 2012, Džankić 2012, Krasniqi 2012) and conflicts were still part of the reality of the region after 1995 when the war in Bosnia and Herzegovina was over. Thus, it might be said that the transitional processes began effectively in all new states, except Slovenia, only with the beginning of the next decade. This is not to deny that in economic terms transition had already begun in the majority of the former republics even during the previous citizenship regime, albeit again quite unevenly. In political, social and cultural terms, however, the effects of transition were not as clear, since it was often vaguely defined as a "qualitative turn in realization of the new way of life, promoting autonomy/freedom and responsibility of all members of society in making constitutive life decisions and choosing the most favourable alternatives" (Golubović 2012, 26).

Post-socialist, post-conflict, post-Yugoslav consolidated states also enabled various forms of gendered transformation in the sphere of labour, welfare and care, thus continuing the process of depoliticisation of women which had already begun in the 1990s. The economic reintegration, liberalisation and restructuring are in many ways dependent on gendered social arrangements. Instead of being romanticised as an ideal of hard-won freedom, the transition rapidly reveals itself as something overwhelmingly associated with "quasi-retraditionalization" (Mićunović 2012, 64) or

\footnotetext{
17 Private interview, 6.2.13, Zagreb.

18 Probably the most eloquent statement on why feminist activism could have been understood as the political itself, as something that is beyond both party politics and the grudges on the broadly defined democratic scene in the post-Yugoslav region, was given by Hana Ćopić, a feminist activist from Belgrade: "Advocating feminism granted one with credibility and comprehensiveness (this position assumes anti-militarism, open anti-nationalism, the staunch belief in emancipation of women, and queer politics). The only space where the two slogans - 'We are all LGBT' and 'Albanians are our Sisters' [banners held during the vigils of Women in Black throughout Serbia] - had currency, was the feminist space" (Private interview, 25.1.13, Berlin).
} 
re-patriarchalisation (Daskalova et al. 2012, Burcar 2013), which in effect combines nationalist downgrading of women to mere bodies obligated to reproduce the nation, and shrinking of the social citizenship of women. Gender regime in the post-socialist and post-conflict citizenship regime revolves around "the desire to re-establish the idyllic family life of the pre-socialist era, including a clear and traditional separation of gender roles" (Kaser 2011, 323), the desire closely connected to the context of conflicts, and also supported by the neoliberal vision of the flexible re-domestication of women.

Regardless of the differences in the pace of transition and the variable success in implementation of the Europeanisation discourses, there are sufficient similarities between the states and the feminist initiatives particular to each of them that allow us to think in terms of post-Yugoslav feminism. Disillusionment is common to many of its representatives. Paula Petričević from Kotor insists that the "impossibility of peaceful transformation of the socialist state left us in the middle of nowhere in an endless transition, devastated by neoliberal capitalism that legalized looting and 'primitive accumulation' of capital", which led to a double breach of the promise of an active citizenship. ${ }^{19}$ Nade Kačakova from Skopje highlighted this by saying that transition "pushes women into financial dependence and poverty that is in conflict with the very idea of active citizenship" ${ }^{20}$ The understanding of transition as something that will enable active democratic citizenship (and give feminists the opportunities to participate in its building) has been, more or less eagerly, supplanted with the description of transition as a series of backlashes. At this point and only recently, a new form of dissenting feminist activism emerged.

\section{From Disenchanted Activists to Partisans of Emancipation}

With the cessation of conflicts, feminists ceased to be disloyal citizens. ${ }^{21}$ That does not mean that they became complacent, uncritical and complying subjects, or that they have suddenly discovered patriotism. What really happened is that they accepted their situatedness. And this tremendous shift from displacement to situatedness has to be understood as a result of several significant factors. The seven states that emerged out of one were acknowledged as the legal, administrative and political

\footnotetext{
19 Private interview, 28.1.13, Kotor.

${ }^{20}$ Private interview, 27.1.13, Skopje.

${ }^{21}$ It needs to be noted that Women in Black were - and still are - isolated in their perseverance to remain disloyal. As 'silence breakers' or 'memory activists', they purposefully stood up against consensus and embraced the stigma of traitorship (Fridman 2011, 509) once ascribed to all (nonpatriotic) feminists. They were persistent in their actions against denial and exoneration of crimes. The major project of Women in Black today is the Women's Court for the Former Yugoslavia, "which represents an attempt to bring justice to those citizens, due to the gendered nature of injustice affecting them, who are almost never subjects of justice, to weave women's experiences in the tissue of public memories and political communities, to enforce the regional and international network of support and solidarity, and to challenge the hidden matrices which hinder women from becoming, being and acting as full-scale citizens" (Zaharijević 2012).
} 
frameworks that enable, support and delimit action. For the first time, the states were regarded in their Westphalian frame, as Nancy Fraser put it, and as the principal addressees of feminist demands. Feminists started to insist on the responsibilities of the states towards women, and they called upon the status of women as citizens of their respective states in defence of women's rights. The gradual institutionalisation of women's issues (some of which had already been revealed by Yugoslav feminists such as domestic violence - and augmented during the nation-building processes and as such were constantly on feminist agendas) led to the commitment of some feminists to the working of the state institutions. In their efforts, post-Yugoslav feminists did not differ much from their European counterparts: their most prominent tasks revolved around different gender-mainstreaming projects - passing of the laws regarding discrimination, advocating greater participation of women in politics, and fighting against gender-related violence (which involves education of police officers, social workers and the personnel of medical centres, i.e. people who represent state structures). The promises of gender mainstreaming, or the strategy of incorporation of gender equality perspective in all policies at all levels and at all stages (Council of Europe 1998, 15, also Verloo 2001), make activism redundant. As policy makers, (Montenegrin, Croatian, Macedonian, Kosovar etc.) governments are responsible for the recognition of gender inequality and the consequent production of equality. Hence, in transitional citizenship regimes the greatest majority of feminists have been either involved in furthering gender mainstreaming politics, or they accept it as inevitable, however reluctantly.

The picture, however, cannot be complete without the contextualisation of the transformation of the so called civil society. In their introduction to Women and Citizenship in Central and Eastern Europe, Lukić, Regulska and Zaviršek state that the emergence of the women's NGO scene in the post-1989 political landscape permitted women to formulate different strategies of survival, engagement, and resistance, and to practice active citizenship in the spaces which were neither inside nor completely outside the state $(2006,3)$. This in-betweenness of civil society was even more highlighted in times of conflicts, when it was almost the only place for practicing citizenship. In the transitional citizenship regime, however, civil society will become increasingly technocratic, managerial and structured, and sometimes openly contradictory to the logic of activism itself.

On the other hand, independence from local governments did not, of course, assume a form of absolute independence: it entailed dependence on foreign governments and international organizations - on their funds, but also on their visions; the production of "feminism-by-design" programmes (Ghodsee 2006) which do not correspond entirely to the needs and interests of local women; willing participation in "humanitarian industry" (Ong 2006); a lack of effort to build upon the existing positive experiences of socialism in order to be adequately Westernised;22

\footnotetext{
${ }^{22}$ In the beginning of the 1990s, when at first glance the differences between East and West seemed gigantic, there were also some promising traits of their theorising. Ann Snitow, for example, indicated
} 
and a general reluctance to overstep the line of the now all too narrow and unsuitable definition of the political in feminist terms. By fighting only the effects and not tackling the causes, feminists began to avoid confronting the dominant political paradigm in post-socialist, post-conflict citizenship regimes.

Destabilizing this political paradigm would, as Lilijana Burcar (2013) said, "entail a useful systemic analysis and a call for destruction of such a system, but this kind of feminism is very dangerous for the so called capitalist democracies". This kind of call is, however, in line with the idea of activist citizenship, which subverts the rules of enactment of a certain citizenship regime. The emphatic difference between active and activist citizenship, defined in Isin and Staeheli, and Faranak Miraftab's distinction between invited and invented spaces of citizenship, will be again helpful here. As Staeheli (2011) argued, active citizenship has a goal of getting things done. It is being enacted in 'invited' spaces, legitimised by donors and government interventions, with the view to provide "coping mechanisms and strategies to survive the adverse effects of the existing social and political hierarchies" (Miraftab 2004, 3). Activist citizenship, on the other hand, wants to challenge and transform the status quo, and is enacted in the 'invented' spaces of practice, often practices of resistance to the dominant systems of exploitation and oppression.

With this in mind, it can be argued that the transitional citizenship regime produced the space for adjustment of feminism. Former feminist disloyalty gave way to the dedicated but disenchanted production of active citizens: of the more genderequalised participation in public affairs by making the rules of participation as diverse as possible. On the other hand, the transitional citizenship regime engendered the new emancipatory feminist political force as well, which might be understood as the space for the post-Yugoslav feminist citizenship, which is yet to evolve. If feminist citizenship in SFRY has to be seen in the context of dissidence, while feminist citizenship in the context of nation-building needs to be assessed by its relationship to belonging and borders, then the post-Yugoslav feminist citizenship needs to be understood in terms of the political re-appropriation and re-politicization of Yugoslav socialist heritage. This re-politicisation needs to be seen not only in the context of a rigorous critique of socio-economic relations brought by neoliberal capitalism, but also within the specific post-conflict and post-socialist circumstances. The invented space of its enactment is not the space of the state: of either former socialist state (SFRY) or any of the new states. It therefore aims to remain outside and above the state: non-ethno-national, not belonging to governments, not depending

\footnotetext{
how East and Central European experience of public/private divide might offer a convenient occasion to rethink the way it was being thought in the West $(1995,144)$. However, this has never happened (there are of course notable exceptions; see Slapšak 1996, 2000). It focused instead on the contemporary global (i.e. Western) theoretical trends, which led not only to obliteration of the specificities of Yugoslav context, but also, according to Ankica Čakardić, to its de-politicisation and rejection of the "issues such as the relations between productive and unproductive labour, strategies of feminist struggle and gender in a class perspective" (Čakardić, forthcoming).
} 
on non-political visions of capitalist democracies. This feminist citizenship merits its name not because of the new wave of Yugo-nostalgia, ${ }^{23}$ but because of the nature of the political itself which is seen to be derivable from the Yugoslav legacy. Or, as Jelena Petrović and Damir Arsenijević say, feminism has to remain "beyond the embrace of the state (vandržavni), that is political - 'Yugoslav'” $(2011,7)$.

\section{Full circle}

In her text “Women's Time in Yugoslavia”, published in 1993, Daša Duhaček wrote:

The women of Yugoslavia did not learn the lesson in citizenship as a way of constructing political subjectivity. Instead, a thin layer of ideologically based egalitarianism was superimposed on a stable patriarchy. Time did make it grow thicker, especially at certain points, as at the level of legislation. Perhaps, given more time, women in Yugoslavia would have won political subjectivity, making use of legislation that was to their advantage. History took another course. (Duhaček 1993, 135-136)

Duhaček was not alone in her assessment of the winning of the political subjectivity. Although it purportedly emancipated women, the socialist form of patriarchy actually diminished their capacity to use and practice citizenship, because women were "lulled into passivity as a political force, by 'emancipation': they were given their rights by the state, instead of being obliged to fight for them, and hence do not know now how to defend them" (Papić 1992, 101, italics mine).

This kind of reading needs to be interpreted in its own time. That time was the time when history took another course: when feminist activism was framed by its opposition to rifles and war, even if that assumed abandoning its own tradition of emancipation. In this paper I wanted to show how changes in citizenship regimes produced imminent changes in gender regimes, which had direct repercussions on feminist activism. I especially wanted to emphasize how contexts, terrains and understanding of emancipation - as well as what feminism as the political force refers to - changed with the changes in citizenship regimes. At the beginning of the 1990s, feminist activists felt that the time had been taken away from them, and with no foreseeable time ahead they also dismissed what had come to pass. Thus, instead of relying on a veritable tradition of partisan women who were fighting with rifles in

\footnotetext{
${ }^{23}$ Although it is not a matter of Yugo-nostalgia, this return to the socialist roots needs to be interpreted as a generational shift as well. The leftist feminists were born in SFRY (or even after), but they lack personal reminiscences of the era. Many have started to gain activist experience during the 1990s or soon after. Many felt the unbearable combination of post-socialist arrangements and post-conflict circumstances on their own skin. In terms of the solidarity across borders, they passed borders between former republics as the state borders, accepting that they exist as if they always existed (Nađa Duhaček, private interview, 19.1.13, Beograd). Intimately, most of them would more easily subscribe to the consciously feminist internationalism captured by the sequel of "I as a woman have no country"- "As a woman, my country is the whole world".
} 
their arms - although not for their rights and against the state, but for the state that would enable not only their citizenship, but just and righteous distribution of rights and duties to all - feminists relied on an invented emancipatory vision, since the course that history had taken altered the frames of interpretation and action. Feminist citizenship of the time was premised on a metaphor: with no clear future and with a turbid, obliterated past, they, as women, had no country.

But with the transformations of citizenship regimes, the feminist relationship towards the state changed. So did the terms of the activist claiming to justice. If feminist citizenship is seen as an effect of these transformations, it also has to be seen as a remonstrance against their complete normalisation and an abiding challenge to the enactment of a certain citizenship regime. That is the only way to explain the fact that partisan women, forgotten as a political force and as the root of the political subjectivity, are now again being honoured as the common and worthy political ancestors of post-Yugoslav feminist citizens. 


\section{Bibliography}

Antić, Milica (1992), "Yugoslavia. The transitional spirit of the age", in Chris Corrin (ed.), Superwomen and the Double Burden. Women's experience of change in central and eastern Europe and the former Soviet Union, London: Scarlet Press.

Balibar, Etienne (1988), “Propositions on Citizenship”, Ethics, Vol. 98, No. 4: 723-730.

Batinić, Jelena (2001), “Feminism, Nationalism, and War: The 'Yugoslav Case' in Feminist Texts", Journal of International Women's Studies, 3(1): 1-23.

Benderly, Jill (1997). "Rape, Feminism, and Nationalism in the War in Yugoslav Successor States", in Lois A. West (ed.), Feminism and Nationalism, New York: Routlegde.

Bilić, Bojan (2012), We were Gasping for Air. (Post-)Yugoslav Anti-War Activism and its Legacy, Baden-Baden: Nomos.

Bollobás, Enikö (1993), “'Totalitarian Lib': The Legacy of Communism for Hungarian Women", in N. Funk and M. Mueller (eds.), Gender Politics and Post-Communism. Reflections from Eastern Europe and the Former Soviet Union, New York and London: Routledge.

Bonfiglioli, Chiara (2011), “'Social Equality is not Enough, We Want Pleasure!' Italian Feminists in Belgrade for the 1978 'Comrade Woman' Conference", Profemina, Special Issue, Summer/Autumn 2: 115-123.

Božinović, Neda (1996), Žensko pitanje u Srbiji u XIX i XX veku, Beograd: Devedesetčetvrta i Žene u crnom.

Braidotti, Rosi (2013), "Interview with Rosi Braidotti: Enacting Citizenship" by Amandine Scherrer, 24 April 2013. Available at http://www.oecumene.eu/news/interview-with-rosibraidotti-enacting-citizenship [accessed on 30.4.2013]

Brown, Wendy (1992), “Finding the Man in the State”, Feminist Studies, Vol. 18, No. 1: 7-34.

Burcar, Lilijana (2013), “Feminizam se sustavno ometa NGO-izacijom”, Novosti, No. 682. Available at http://www.novossti.com/2013/01/feminizam-se-sustavno-ometa-ngo-izacijom/ [accessed on 8.4.2013]

Cockburn, Cynthia (1998), The Space between Us. Negotiating Gender and National Identities in Conflict, London and New York: Zed Books.

Corrin, Chris (1999), "Rethinking Citizenship: Analyses and Activism in Central and Eastern Europe", Journal of Communist Studies and Transition Politics, Vol. 15, No. 1: 64-82.

Council of Europe (1998), Conceptual Framework, Methodology and Presentation of Good Practices: Final Report of Activities of the Group of Specialists on Main-streaming. Strasbourg: Council of Europe. 
Ćetković, Nadežda (ed.) (1998), Ženska politička perspektiva, Beograd: Beogradski ženski lobi. Čakardić, Ankica, forthcoming, “Women's problem in political economy: from Yugoslav self-management to austerity measures".

Čačinovič-Puhovski, Nadežda (1976), „Ravnopravnost ili oslobođenje. Teze o teorijskoj relevantnosti suvremenog feminizma“, Žena, No. 3: 125-128.

Daskalova Krassimira, C. Hornstein-Tomic, K. Kaser and F. Radunovic (eds.) (2012), Gendering Post-Socialist Transition, ERSTE Foundation Series.

Deschaumes, Ghislaine Glasson and Svetlana Slapšak (2003), "Žene Balkana za mir: aktivistkinje prelaze granice", special edition, Profemina, No. 31-32.

Despot, Blaženka (1981), “Žena i samoupravljanje”, Delo, Vol. XXVII, No. 4: 112-116.

Despot, Blaženka (1987), “Žensko pitanje' u socijalističkom samoupravljanju”, in Lydia Sklevicky (ed.), Žena i društvo. Kultiviranje dijaloga, Zagreb: Sociološko društvo.

Dobnikar, Mojca (2000), “War, Discourse, Women - What about Us?”, in Svetlana Slapšak (ed.), War Discourse, Women's Discourse, Ljubljana: Topos.

Drakulić, Slavenka (1984), “Smrtni grijesi feminizma”, in Lydia Sklevicky (ed.) (1987), Žena i društvo. Kultiviranje dijaloga, Zagreb: Sociološko društvo.

Drezgić, Rada (2010), „Bela kuga“ među "Srbima“. O naciji, rodu i rađanju na prelazu vekova, Beograd: IFDT i Albatros plus.

Duhaček, Daša (1993), "Women's Time in the Former Yugoslavia", in N. Funk and M. Mueller (eds.), Gender Politics and Post-Communism. Reflections from Eastern Europe and the Former Soviet Union, New York and London: Routledge.

Džankić, Jelena (2012), “Understanding Montenegrin citizenship”, in Shaw and Štiks (eds.), Citizenship After Yugoslavia, Routlegde.

Einhorn, Barbara (1993), Cinderella Goes to Market. Citizenship, Gender and Women's Movement in East Central Europe, London: Verso.

Fraser, Nancy (2009), "Feminism, Capitalism and the Cunning of History", New Left Review, No. 56: 97-117.

Fridman, Orli (2011), "'It was like fighting a war with our own people': anti-war activis in Serbia during the 1990s", Nationalities Papers, Vol. 39, No. 4: 507-522.

Gal, Susan (1997), "Feminism and Civil Society", in M. Feischmidt, E. Magyari Vincze and V. Zentai (eds.), Women and Men in East European Transition, Cluj-Napoca: EFES. 
Gal, Susan and Gail Kligman (eds.) (2000), Reproducing Gender: Politics, Publics and Everyday Life after Socialism, Princeton University Press.

Ghodsee, Kristen (2006), “Nongovernmental Ogres? How Feminist NGOs Undermine Women in Postsocialist Eastern Europe", The International Journal of Not-for-Profit Law, Vol. 8, No. 3. Available at http://www.icnl.org/research/journal/vol8iss3/art_2.htm[accessed on 10.4.2013]

Golubović, Zagorka (2012), „Tranzicija u Srbiji posle 2000. godine - lavirinti tranzicije“, in Zoran Stojiljković (ed.), Lavirinti tranzicije, Beograd: FES i Centar za demokratiju.

Hayden, Robert (1992), "Constitutional Nationalism in the Formerly Yugoslav Republics", Slavic Review 51 (4): 654-673.

Hayden, Robert (1999), Blueprints for a House Divided. The Constitutional Logic of the Yugoslav Conflicts, University of Michigan.

Heinen, Jacqueline (2006), “Clashes and Ordeals of Women's Citizenship in Central and Eastern Europe", in J. Lukić, J. Regulska and D. Zaviršek (eds.), Women and Citizenship in Central and Eastern Europe, Ashgate.

Isin, Engin (2009). "Citizenship in Flux: The Figure of the Activist Citizen", Subjectivity, 29, 367-388.

Iveković, Rada i Slavenka Drakulić (1984), “Yugoslav Neofeminism and its 'Six Mortal Sins'", in Robin Morgan (ed.) (1996), Sisterhood is Global. The International Women's Movement Anthology, New York: Feminist Press at the City University of New York.

Iveković, Rada (1987), “Studije o ženi i ženski pokreti”, in Lydia Sklevicky (ed.), Žena i društvo. Kultiviranje dijaloga, Zagreb: Sociološko društvo.

Iveković, Rada (1993), “Women, Nationalism and War: 'Make Love Not War'”, Hypatia, Vol. 8, No. 4: 113-126.

Iveković, Rada and Julie Mostov (eds.) (2001), From Gender to Nation, Ravenna: Longo Editore.

Jalušič, Vlasta (1999), “Women in Post-Socialist Slovenia: Socially Adapted, Politically Marginalized", in S. Ramet (ed.), Gender Politics in the Western Balkans.

Jambrešić-Kirin, Renata (2000), “Personal Narratives of War: A Challenge to Women's Essays and Ethnography in Croatia", in Svetlana Slapšak (ed.), War Discourse, Women's Discourse, Ljubljana: Topos.

Jansen, Stef (2005), Antinacionalizam: etnografija otpora u Zagrebu i Beogradu, trans. Aleksandra Bajazetov, Beograd: XX vek. 
Jones, Kathleen B. (1997), "Introduction to the special issue on Citizenship in Feminism: Identity, Action, and Locale", Hypatia, Vol. 12, No. 4: 1-5.

Kaser, Karl (2011), The Balkans and the Near East. Introduction to a Shared History, Wien: Lit.

Kašić, Biljana (1995), “December 1992 - The Beginning", in What Can We Do For Ourselves? Belgrade: Center for Women's Studies, Research and Communication.

Kesić, Vesna (2001), "Gender and Ethnic Identities in Transition in the Former Yugoslavia Croatia", in R. Iveković and J. Mostov (eds.), From Gender to Nation, Ravenna: Longo Editore.

Koprivnjak, Vjekoslav (1980), “Uvodnik u temat", Žena, No. 4-5: 6-15.

Krasniqi, Vjollca (2011), "Feminism and Nationalism", Profemina, Special Issue, Summer/Autumn 2: 53-57.

Krasniqi, Gëzim (2012), “Overlapping Jurisdictions, Disputed Territory, Unsettled State: The Perplexing Case of Citizenship in Kosovo", in Shaw and Štiks (eds.), Citizenship After Yugoslavia, Routlegde.

Ler-Sofronić, Nada (1981), "Subordinacija žene - sadašnjost i prošlost", Marksistička misao, No. 4: 73-80.

Lister, Ruth (1990), "Women, Economic Dependency and Citizenship", Journal of Social Policy, 19: 445-467.

Lister, Ruth (1997), “Citizenship: Towards a Feminist Synthesis”, Feminist Review, No. 57: 2848 .

Lukić, Jasmina, Joanna Regulska and Darja Zaviršek (2006), “Introduction”, in Lukić, J. Regulska and D. Zaviršek (eds.), Women and Citizenship in Central and Eastern Europe, Ashgate.

Marshall, T. H. (2009 [1950]), "Citizenship and Social Class", in Jeff Manza and Michael Sauder (eds.), Inequality and Society, New York: W. W. Norton and Co.

Mertus, Julie (1999), "Women in Kosovo: Contested Terrains", in Sabrina P. Ramet (ed.), Gender Politics in the Western Balkans, Pennsylvania State University.

Mićunović, Natalija (2012), „Odustajanje od ideologije i preuzimanje odgovornosti“, in Zoran Stojiljković (ed.), Lavirinti tranzicije, Beograd: FES i Centar za demokratiju.

Milić, Anđelka (1981), "Društvena jednakost polova: savremena teorijska preispitivanja", Marksistička misao, Vol. 4: 3-15.

Mimica, Aljoša and Radina Vučetić (2008), Vreme kada je narod govorio, Beograd: Institut za sociološka istraživanja. 
Miraftab, Faranak (2004), “Invited and Invented Spaces of Participation: Neoliberal Citizenship and Feminists' Expanded Notion of Politics", Wagadu, Vol. 1: 1-7.

Miroiu, Mihaela (2007), "Communism was a State Patriarchy, not State Feminism", Aspasia, Vol. 1: 197-201.

Morokvasic, Mirjana (1986), "Being a Woman in Yugoslavia: Past, Present and Institutional Equality", in Monique Gadant (ed.), Women of the Mediterranean, London: Zed Books.

Narayan, Uma (1997), “Towards a Feminist Vision of Citizenship: Rethinking the Implications of Dignity, Political Participation, and Nationality", in Mary Lyndon Shanley and Uma Narayan (eds.), Reconstructing Political Theory: Feminist Perspectives, Cambridge: Polity Press.

Nikolić-Ristanović, Vesna (2000), “From Sisterhood to Non-Recognition: Instrumentalization of Women's Suffering in the War in the Former Yugoslavia", in Svetlana Slapšak (ed.), War Discourse, Women's Discourse, Ljubljana: Topos.

Ong, Aihwa (2006), "Mutations in Citizenship", Theory, Culture and Society, Vol. 23(2-3): 49953.

Pantelić, Ivana (2011), Partizanke kao građanke. Društvena emancipacija partizanki u Srbiji 19451953, Beograd: ISI i Evoluta.

Papić, Žarana (1992), “The Possibility of Socialist Feminism in Eastern Europe”, in: Ward, Anna, Jeanne Gregory \& Nira Yuval-Davis (eds.), Women and Citizenship in Europe, Trentham Books \& European Forum of Socialist Feminists, London.

Papić, Žarana (2002), “Europe after 1989: Ethnic Wars, the Fascitization of Civil Society and Body Politics in Serbia", in Griffin G. and R. Braidotti (eds.), Thinking Differently: A Reader in European Women's Studies. London: Zed Books.

Papić, Žarana (2012), To je moj izveštaj vamal This is My Report to You, Belgrade: Rekonstrukcija ženski fond.

Pateman, Carole (1988), Sexual Contract, Stanford University Press.

Pateman, Carole (2011). "Securing Women's Citizenship: Indifference and Other Obstacles", Eurozine. Available at http://www.eurozine.com/articles/2011-03-07-pateman-en.html [accessed on 27.3.2013]

Pavlović, Tatjana (1999), "Women in Croatia: Feminists, Nationalists, and Homosexuals", in Ramet Sabrina (ed.), Gender Politics in the Western Balkans. 
Pavlović, Tatjana (2001), "Remembering/Dismembering the Nation: The Archeology of Lost Knowledge", in R. Iveković and J. Mostov (eds.), From Gender to Nation, Ravenna: Longo Editore.

Petrović, Jelena (2009), “The Politics of Feminist Writing/Reading/Translation”, Borec LXI, št. 662-665: 239-257.

Petrović Jelena and Damir Arsenijević (2011), "The True Space of Yugoslav Feminisms", Profemina, Special Issue, Summer/Autumn 2: 7-11.

Pusić, Vesna (1980), “Protiv psihologije odgađanja”, in Lydia Sklevicky (ed.) (1987), Žena i društvo. Kultiviranje dijaloga, Zagreb: Sociološko društvo.

Ragazzi, Francesco (2011), “Towards Post-Territorial Citizenship?". Available at http://www.citsee.eu/citsee-story/towards-post-territorial-citizenship [accessed on 27.3.2013]

Ramet, Sabrina (1995), Social Currents in Eastern Europe, Duke University Press.

Ramet Sabrina (ed.) (1999), Gender Politics in the Western Balkans, Pennsylvania: The Pennsylvania State University Press.

Ramet, Sabrina P. (1999), "In Tito's Time", in S. Ramet (ed.), Gender Politics in the Western Balkans.

Rihtman-Auguštin, Dunja (1980), “Moć žene u patrijarhalnoj i suvremenoj kulturi”, Žena, No. 4-5:

Shaw, Jo and Igor Štiks (2012), Citizenship After Yugoslavia, Routlegde.

Slapšak, Svetlana (1996), “Žene i rat u bivšoj Jugoslaviji”, Republika, No. 145-146. Available at http://www.yurope.com/zines/republika/arhiva/96/145/145-16.html [accessed on 27.3.2013]

Slapšak, Svetlana (2000), "Yugoslav War: A Case of/for Gendered History", in S. Slapšak (ed.), War Discourse, Women's Discourse. Essays and Case-Studies From Yugoslavia and Russia, Ljubljana: Topos.

Sklevicky, Lydia (1987), “Konji, žene, ratovi itd.: problem utemeljenja historije žena u Jugoslaviji", in Žena i društvo. Kultiviranje dijaloga, Zagreb: Sociološko društvo.

Snitow, Ann (1995), "Feminist Futures in the Former East Bloc", in What Can We Do For Ourselves? Belgrade: Center for Women's Studies, Research and Communication.

Sparks, Holloway (1997), "Dissident Citizenship: Democratic Theory, Political Courage, and Activist Women", Hypatia, Vol. 12, No. 4: 74-110. 
Squires, Judith (2000), "The State in (and of) the Feminist Vision of Political Citizenship", in Catriona McKinnon and Iain Hampsher-Monk (eds.), The Demands of Citizenship, London and New York: Continuum.

Staeheli, Lynn A, "Youth and Citizenship: Struggles on and off the Street", paper presented at Royal Holloway University Workshop City/State/Resistance, December 2011, London. Available at http://backdoorbroadcasting.net/2011/12/lynn-staeheli-youth-and-citizenshipstruggles-on-and-off-the-street/ [accessed on 22.3.2013].

Stubbs, Paul (2012), "Networks, Organisations, Movements: Narratives and Shapes of Three Waves of Activism in Croatia", Polemos, Vol. 15, No. 2: 11-32.

Stubbs, Paul (2007), "Civil Society of Ubleha?", in H. Rill, T. Šmidling and Ana Bitoljanu, 20 Pieces of Encouragement for Awakening and Change, Belgrade-Sarajevo: Centre for Nonviolent Action.

Šeleva, Elizabeta (2004). "Kuća i nelagoda". Sarajevske sveske, No. 5. Available at http://www.sveske.ba/bs/content/kuca-i-nelagoda [accessed on 22.12.2012].

Štiks, Igor (2012), “A Laboratory of Citizenship: Shifting Conceptions of Citizenship in Yugoslavia and post-Yugoslav states", in Shaw and Štiks (eds.), Citizenship After Yugoslavia, Routlegde.

Tito, Josip Broz (1979), „Šezdeset godina revolucionarne borbe Saveza Komunista Jugoslavije“, Žena, No. 2-3: 2.

Vasiljević, Jelena (2012), “Imagining and managing the nation: tracing citizenship policies in Serbia", in Shaw and Štiks (eds.), Citizenship After Yugoslavia, Routlegde.

Verdery, Katherine (1996). What was Socialism and What Comes Next?, Princeton: Princeton University Press.

Verdery, Katherine (1998). "Transnationalism, Nationalism, Citizenship, and Property: Eastern Europe Since 1989", American Ethnologist, Vol. 25, No. 2: 291-306.

Verloo, Mieke (2001), Another Velvet Revolution? Gender mainstreaming and the politics of implementation. IWM Working Paper No. 5: Vienna.

Walby, Sylwia (1997), “Is Citizenship Gendered?", in Gender Transformation, New York and London: Routledge.

Woodward, Susan L. (1985), “The Rights of Women: Ideology, Policy, and Social Change in Yugoslavia", in S. Wolchik and A. Meyer (eds.), Women, State, and Party in Eastern Europe, Duke University Press

Yuval-Davis, Nira (1991). „The Citizenship Debate: Women, Ethnic Processes and the State“, Feminist Review, no. 39, winter, pp. 58-68. 
Zaharijević, A., Duhaček D. and Ivanović, Z. (eds.) (2012), Žarana Papić. Tekstovi 1977-2002, Beograd: Centar za studije roda i politike, Rekonstrukcija ženski fond i Žene u crnom.

Zaharijević, Adriana (2012), “On Trial at the Women's Court: Gender Violence, Justice and Citizenship". Available at http://www.citsee.eu/citsee-story/trial-women\%E2\%80\%99s-courtgender-violence-justice-and-citizenship [accessed on 9.4.2013]

Zajović, Staša (1995a), "Birth, Nationalism and War". Available at http://www.hartfordhwp.com/archives/62/039.html [accessed on 1.4.2013].

Zajović, Staša (1995b), "I am Disloyal”, in What Can We Do For Ourselves? Belgrade: Center for Women's Studies, Research and Communication.

Žarkov, Dubravka (2003), "Feminism and the Disintegration of Yugoslavia: On the Politics of Gender and Ethnicity", Social Development Issues, Vol. 24, No. 3: 59-68. 

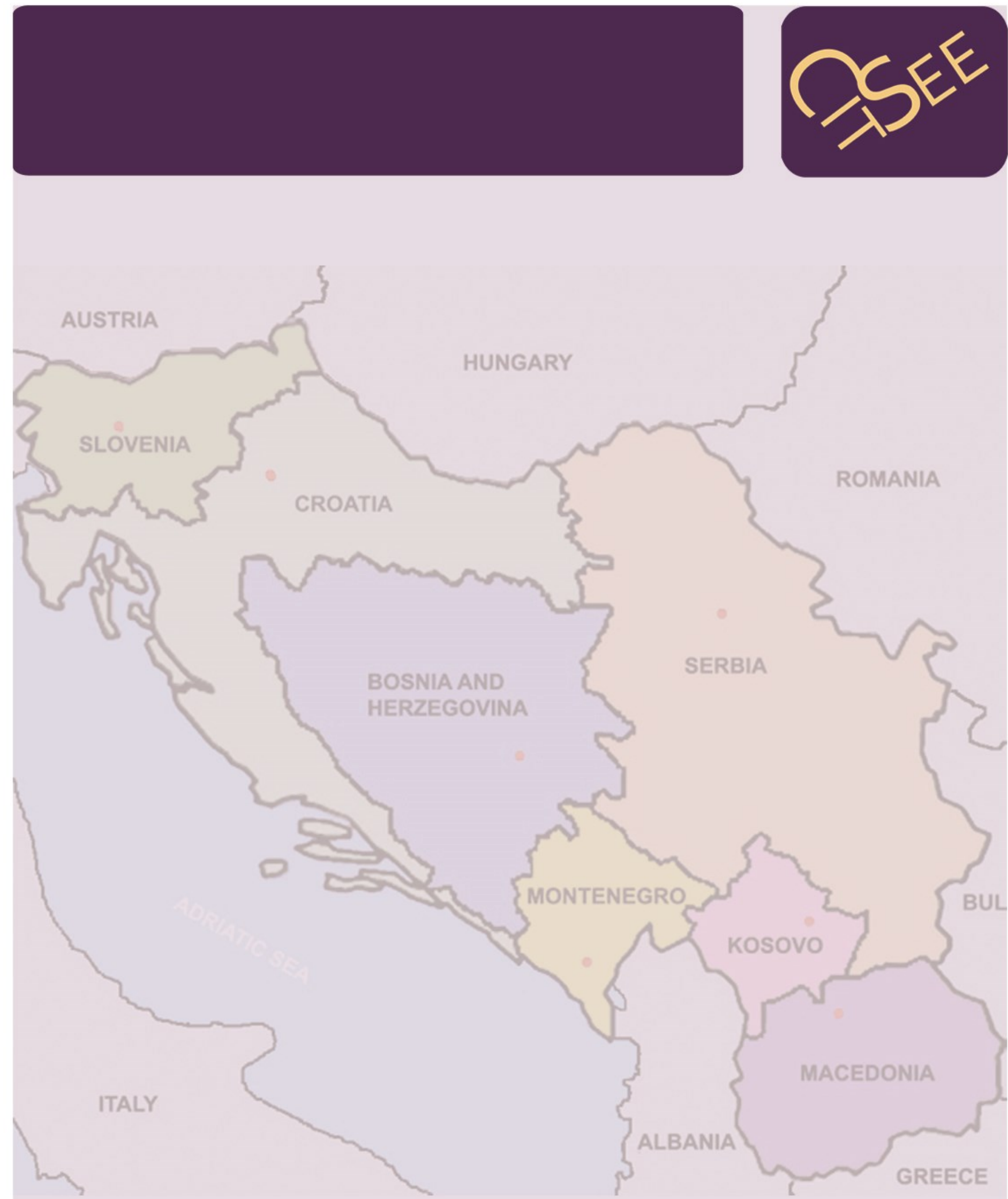

I S SN 2046-4096

The EuRopeanisation OF Citizenship in the SuCCESSOR States of the Former Yugoslavia (CitseE) SCHOOL OF LAW, THE UNIVERSITY OF EDINBURGH,

OLD COLLEGE, SOUTH BRIDGE

EDINBURGH, EH 8 GYL, SCOTLAND, UK

WWW, LAW, ED, AC, UK/CITSEE 